\title{
Study on the Effect of Post Harvest Treatments on Shelf Life of Custard Apple (Annona squamosa L.) Variety Arka Sahan during Storage
}

\author{
Megha Patidar $^{1^{*}}$, Jyoti Kanwar ${ }^{1}$, O. P. Singh ${ }^{2}$ and G. P. S. Rathore ${ }^{2}$ \\ ${ }^{1}$ Department of Horticulture, College of Horticulture, Mandsaur, India \\ ${ }^{2}$ Rajamata Vijaya Raje Scindia Krishi Vishwa Vidyalaya, Gwalior, M.P., India \\ *Corresponding author
}

\section{A B S T R A C T}

\section{Keywords}

Custard apple, Arka Sahan, Chitosan, Coating, Shelf life

Article Info

Accepted:

20 December 2020

Available Online:

10 January 2021
A laboratory experiment was conducted on "Study on the effect of post harvest treatments on shelf life of custard apple (Annona squamosa L.) variety Arka Sahan during storage" at department of fruit science, KNK college of horticulture, Mandsaur. Experiment was statistically designed in Complete Randomized Design (CRD) with three replications. There were three components with 13 treatment combinations i.e. Calcium chloride at $2 \%$, $4 \%, 6 \%$, Benzyl adenine at 50ppm, 100ppm, 150ppm, Chitosan at $0.5 \%, 1.0 \%, 1.5 \%$ and their combinations and control. The treated fruits were evaluated for colour, taste, flavour and appearance during storage. The study concluded that higher treatment combination $\left(\mathrm{CaCl}_{2} 6 \%+\mathrm{BA} 150 \mathrm{ppm}+\right.$ Chitosan 1.5\%) treated fruits overall performed best and enhanced the shelf life or to inhibited fruit ripening of custard apple fruits by 12 days at ambient room temperature with good quality as compared to control.

\section{Introduction}

Custard apple (Annona squamosa L.) is one of the finest fruits introduced in India from Tropical America. The undomesticated form of this fruit can be found in many part of India. It is also known as various names like Sugar Apple, sitaphal, sweet sop and sharifa. Fruit ripening nature of custard apple is climacteric i.e. sharp rise in respiration after harvest. Custard apple is very high perishable fruit crop with very short life of storage (Wills et al., 2001). The edible portion or pulp is a creamy and granular with a good blend of sweetness. It contains protein $(1.6 \mathrm{~g})$, fat $(0.5-$ $0.6 \mathrm{~g})$, carbohydrate $(23.5 \mathrm{~g})$, crude fiber (0.9-
$6.6 \mathrm{~g}$ ), calcium (17.6 g), phosphorus (47 mg), iron $(1.5 \mathrm{~g})$, thiamine $(0.075-0.119 \mathrm{mg})$, riboflavin (0.086- $0.175 \mathrm{mg}$ ), ascorbic acid (15.0-44.4 mg) and nicotinic acid $(0.5 \mathrm{mg})$ per $100 \mathrm{~g}$ of edible portion (Mahadevbhai and Patel, 2018). Cold storage is not promising. Moreover if fruit is allowed to remain on the tree for prolonged period, the pericarp splits to open facilitating deterioration. Because of custard apple is highly perishable, the fruits could not be send to distant markets. Commercialization of custard apple (Annona squamosa, L) is the biggest hinder for the custard apple growers due to its highly perishable nature. On an average, the postharvest shelf life of this fruit is only three 
to four days at ambient temperature. Therefore, it can commercialize only in the domestic market. An immediate consequence is a raise of the product's price. Hence, it is mandatory to develop a technology which allows to increase the custard apple post harvest shelf life, available to consumers with good quality and reasonable prize. It is also necessary to develop a technology which enables to extend the sugar apple postharvest shelf life, reaching the consumer with good sensory qualities and available at compensatory prices. Among the different methods, fruit coatings are one such alternative as they do not only improve external appearance, but also modify the internal atmosphere of fruits (Trung et al., 2011).

Use of semi-permeable coatings has gained importance in reducing the moisture loss, transpiration, respiration and microbial attack with maintaining firmness at ambient condition (Patel et al., 2011). Coatings make good oxygen and lipid barrier at low to intermediate $\mathrm{RH}$ because the polymers can effectively make hydrogen bonds (Sihag et $a l .$, 2005). For instance use of benzyl adenine (antioxidant) acts as antisenescent, stop the metabolic break down deterioration caused by various biochemical activities in the fruits (Bhardwaj et al., 2005). Calcium chloride has found promising new technology in maintaining fruit quality during storage, which alternative to disinfestations of fruit and could modify its response to other stresses. Chitosan dissolved in diluted organic acids can be used as a casting fluid to form a preservative membranous coating on the fruits that have been successfully used to maintain the quality and shows antifungal activity against several fungi (Trung et al., 2011; Li and $\mathrm{Yu}, 2001)$. An immediate consequence is a raise of the product's price. Hence, it is necessary to develop a technology which enables to extend the sugar apple postharvest shelf life, reaching the consumer with good sensory qualities and available at compensatory prices by the application of edible coatings.

\section{Materials and Methods}

Custard apple fruits were obtained from a KVK of Chittaurgarh, Rajasthan. The full matured fruits were subjected to uniform manual grading and used for experiment in the laboratory of department of fruit science in plastic crates. The fruits were cleaned with running tap water to remove the adherent dirt material and then spread in room. The fruits were disinfected with $0.1 \%$ (w/v) bavistin solution for 2 minutes then fruits were dipped in the coating solutions of 13 treatment combinations i.e. Calcium chloride at $2 \%$, $4 \%, 6 \%$, Benzyl adenine at 50ppm, 100ppm, $150 \mathrm{ppm}$, Chitosan at $0.5 \%, 1.0 \%, 1.5 \%$ and their combinations and control. The chitosan solution $(1 \%$, wt/vol) was prepared by dissolving $1 \%$ acetic acid to accelerate the dissolution process. The $\mathrm{pH}$ of the chitosan solution was adjusted to 5.6 using I $\mathrm{N} \mathrm{NaOH}$. After applications of treatments fruits were kept in the room temperature in plastic trays. The organoleptic evaluation of custard apple fruits in respect of colour, taste, flavour and appearance were evaluated at $0,4,8$ and 12 days of storage period, by a panel of 5 trained / semi trained judges drawn from the college using 9 point hedonic scale (Amerine et al, 1965).

\section{Results and Discussion}

The observations were presented as initial value (before treatment), 0 day, $4^{\text {th }}$ day, $8^{\text {th }}$ day and $12^{\text {th }}$ day. The change recorded from initial value to $0,4,8,12$ days are depicted in graphs. The experiment was continued for 12 days to preserve fruits with natural quality and overall acceptability. Observations on taste, colour, flavour and appearance have 
been taken four days interval upto $12^{\text {th }}$ day of storage and the significant findings are as follows:

To maintained original colour of custard apple fruits, higher level of treatment combination $\mathrm{T}_{12}$ scored higher $(8.31,8.00$, 6.88 and 3.80) over rest of the treatments at 0 , 4,8 and 12 days of storage period. It was found significantly at par with treatments $\mathrm{T}_{11}$ (8.45, 7.96, 6.86 and 3.76) and $\mathrm{T}_{9}(8.59,7.95$, 6.81 and 3.75) at $0,4,8$ and 12 days of storage period, respectively, $\mathrm{T}_{8}(8.81,3.74)$ on 4 and 12 days, respectively, $\mathrm{T}_{10}$ (3.75) on 12 days of storage period.

The lower scored treatment for retaining of colour was $\mathrm{T}_{0}(8.12,6.80,4,4.66$ and 2.01) at $0,4,8$ and 12 days of storage period, respectively. This may be due to the combined effect of chitosan, benzyl adenine and calcium chloride which decreased early deterioration of external colour of untreated fruits during storage and retardation of senescence process, slower metabolic activities as well as enzyme reaction tended to slower deterioration of internal colour. Chitosan coating offers a defensive barrier against bacterial contamination and loss of moisture from the surface of food products, thus extending their shelf life (Shiek, et al., 2013). These results were also in collaboration with the findings of Pinal et al., (2014) and Tanwar et al., (2004) in custard apple.

It was noticed that, $\mathrm{T}_{12}\left(\mathrm{CaCl}_{2} 6.0 \%+\mathrm{BA}\right.$ $150 \mathrm{ppm}+$ Chitosan $1.5 \%$ ) recorded maximum score for taste of fruits $(4.30,6.69$, 8.73 and 7.84) followed by $\mathrm{T}_{11}(4.39,6.65$, 8.72 and 7.82 ) at $0,0,4,8$ and 12 days of storage respectively, $\mathrm{T}_{9}(4.39,6.64$ and 8.62$)$ at 0,4 and 8 days of storage period respectively, and $\mathrm{T}_{8}(4.31,6.60$ and 8.58$)$ on 0,4 and 8 days of storage period, respectively.

The minimum level of taste was observed with control $\mathrm{T}_{0}(4.27,7.16,6.39$ and 4.47$)$ at $0,4,8$ and 12 days of storage respectively, when the storage period was prolonged, it was observed that taste of fruits deteriorated. It was mainly due to the increase in sugar content during storage. Chitosan coating might be due to the increasing the total soluble solid in the sugar apple fruits during storage. These results corroborates with the finding of Jholgiker and Reddy (2007) in custard apple.

Fig.1 Showed that the colour of custard apple decreased for all treatment during storage period

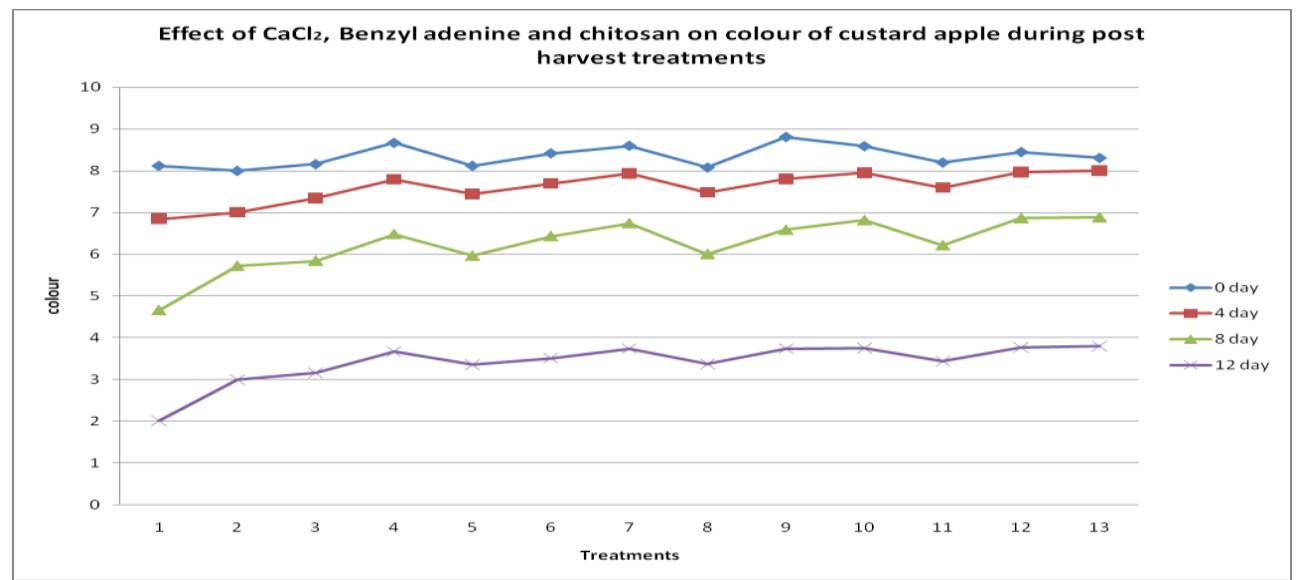


Fig.2 Showed that the taste of custard apple first increased then decreased during storage period with all the treatments

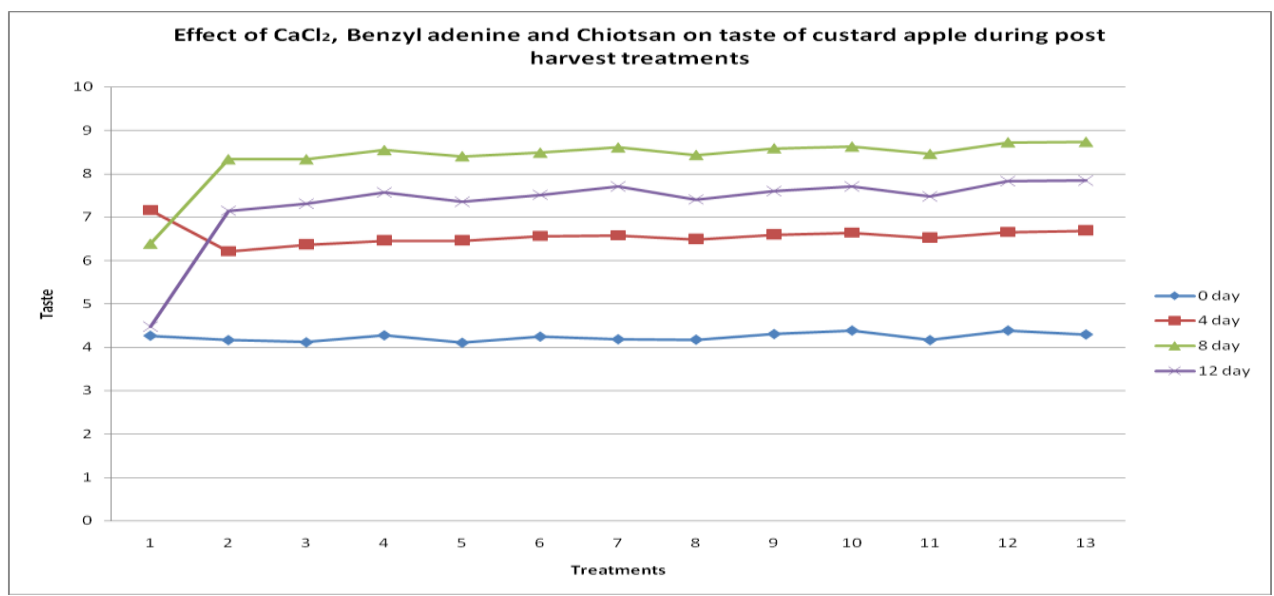

Fig.3 Showed that the flavour of custard apple first increased then decreased during storage period with all the treatments

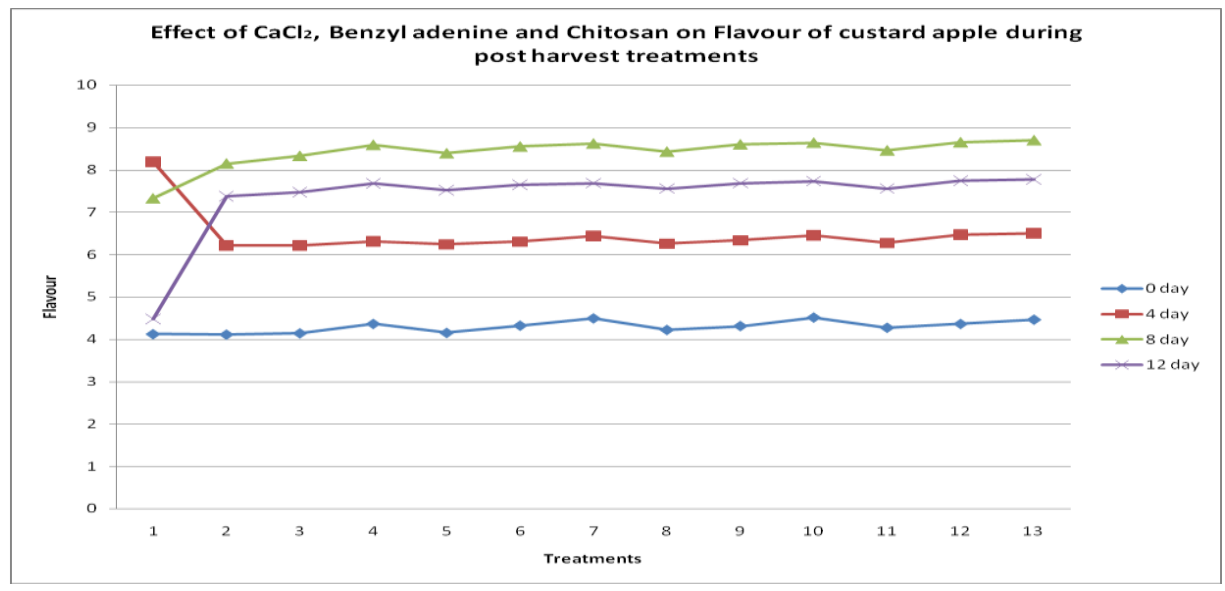

Fig.4 Showed that the appearance of custard apple decreased with all the treatments during storage

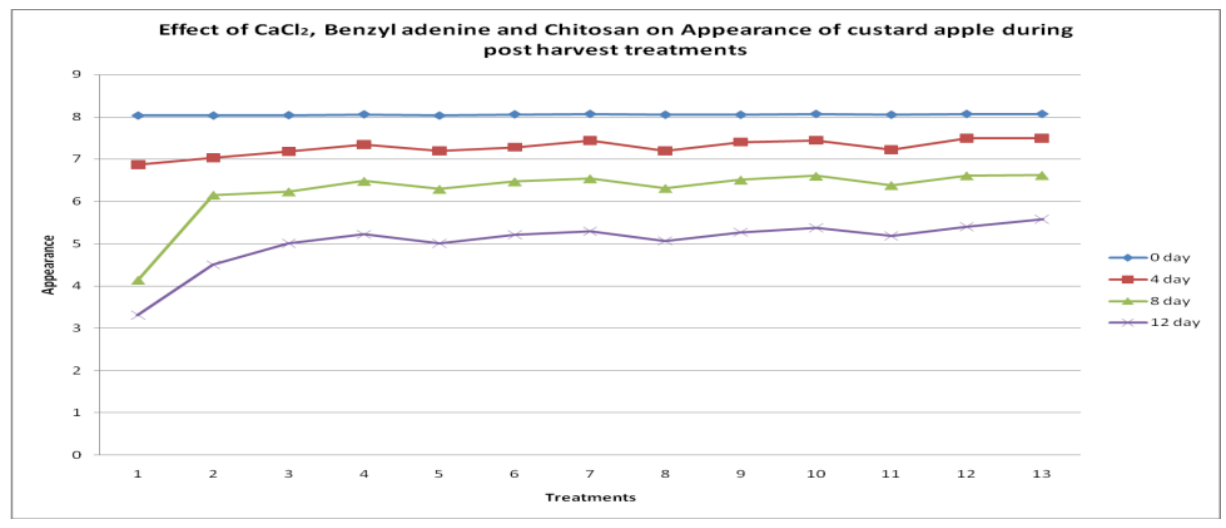


The perusal of data clearly indicated that higher level of treatment combination $\mathrm{T}_{12}$ (4.46, 6.50, 8.70 and 7.77) recorded maximum scored in retaining the fruit flavour at $0,4,8$ and 12 days of storage, respectively. It was also reported statistically at par with the treatment $\mathrm{T}_{11}(4.36,6.47,8.65$ and 7.74$)$ and $\mathrm{T}_{9}$ (4.51, 6.45, 8.64 and 7.73), $\mathrm{T}_{8}$ (4.31, $6.33,8.60$ and 7.68$)$ at $0,0,4,8$ and 12 days of storage, respectively. Whereas, minimum scored in retaining natural flavour $(4.12,8.19$, 7.33 and 4.48$)$ received by control $\left(\mathrm{T}_{0}\right)$ at 0,4 , 8 and 12 days of storage period respectively.

Retain the flavour for longer period of time and release pleasant flavour in chitosan coated fruits might be due to delay ripening of fruits. Similar results were observed by Patil et al., (2014) and patel et al., (2011) when custard apple fruits treated with wax.

Perfect level of appearance showed by treatment $\mathrm{T}_{12}(8.07,7.49,6.62,5.58)$ at 0,4 , 8,12 days of storage period, respectively. It was significantly at par with $\mathrm{T}_{11}(8.07,7.49$ and 6.61), $\mathrm{T}_{9}(8.07,7.44,6.60)$ on $0,4,8$ days, respectively $\mathrm{T}_{8}(8.05$ and 7.40$)$ at 0 and 4 days of storage period, respectively. Whereas appearance continue deteriorated and scored minimum under control $\mathrm{T}_{0}(8.03,6.87,4.13$ and 3.31) at $0,4,8$ and 12 days, respectively. Over-ripening of the fruit facilitates deterioration of nutritional constituents leading the fruit unfit for consumption specified with excessive loss of external appearance (Babu et al., 1990).

This may be due to that the significant effect on organolaptic parameters of chitosan coating increase the shelf life of food by acting as defensive barriers against bacterial contamination and loss of moisture from the surface and it is one of the best edible and biologically safe preservative coatings (Shiek, et al., 2013).

\section{References}

Amerine M.A.; Pangborn R.M.; Rosesler E.B. (1965) Principles of sensory evaluation of foods. Academic, New York, 370.

Babu, K.H.; Zaheeruddin, M.; and Prasad, P.K. (1990). Studies on postharvest storage of custard apple. Acta Horticulturae., 269: 299-300.

Bhardwaj, R. L.; Sen, N. L. and Mukherjee, S. (2005). Effect of benzyl adenine on physic- chemical characterstics and shelf-life of mandarin cv. Nagpur santra. Indian J. Hort. 62: 181-183.

Jholgiker, P. and Reddy, B. S. (2007). Effect of different surface coating material on post-harvest physiology of Annona squamosa L. fruits under ambient and zero energy cool chamber storage. Indian J. Hort. 64(1): 41-44.

Li, H. and $\mathrm{Yu}$, T. (2001). Effect of chitosan on incidence of brown rot, quality and physiological attributes of post harvest peach fruit. J. Sci. Food. Agri. 81: 269274.

Mahadevbhai, C. C. and Patel A. P. (2018). Effect of grading and post-harvest application of chemicals and biochemical parameters of custard apple (Annona squamosal L.) cv. Balanagar. Int. J. Curr. Microbiol. App. Sci. 7(11): 1085-1093.

Patel, N.; Naik, A.G. and Arbat, S. S. (2011). Response of postharvest chemical treatments on shelf life and quality of custard apple $\mathrm{cv}$. balanagar. Indian $J$. Hort. 68(4): 547- 550.

Patil, R. A.; Rao, S.D.V.; Sumitha, N. and Manasa, B. (2014). Sensory quality of custard apple fruits stored at low temperature. Bioinfolet. 11: 858-860.

Pinal, D.; Zurron, M.; Diaz, F. (2014). Effects of load and maintenance duration on the time course of information encoding and retrieval in working memory: from perceptual analysis to post- 
categorization processes. Front. Hum. Neurosci. 8: 165.

Shiekh, R. A.; Malik, M. A.; Al-Thabaiti, S. A. and Shiekh, M. A. (2013). Chitosan as a Novel Edible Coating for Fresh Fruits. Food Sci. Technol. Res., 19 (2): $139-155$

Sihag, R. P.; Behiwal, L. S. and Mehta, P. K. (2005). Effect of postharvest application of potassium permanganate on shelf life of Peach fruit.Haryana. J. Hort. Sci. 34 (3-4): 259-260.

Tanwar, R.K.; Rawat, T.S.; Lakhawat, S.S. (2004) Effect of UV radiation, $\mathrm{MH}$ and $\mathrm{KMnO} 4$ on storage life of Custard apple
(Annona squamosa 1.). Udyanika. 10(3):32-36.

Trung, T. S.; Phuong, N. T. H. and Stevens, W. H. (2011). Protective effect of chitosan coating and polyethylene film wrapping on postharvest storage of sugar-apples. Asian. J. Food Ag- Ind. 4(2): 81-90.

Wills, R.B.H.; Warton, M.A.; Mussa, D. M. D. N. and Chew, L. P. (2001). Ripening of climacteric fruits initiated at low ethylene levels. Austral. J. Expt. Agr. 41 (1): 89-92.

\section{How to cite this article:}

Megha Patidar, Jyoti Kanwar, O. P. Singh and Rathore, G. P. S. 2021. Study on the Effect of Post Harvest Treatments on Shelf Life of Custard Apple (Annona squamosa L.) Variety Arka Sahan during Storage. Int.J.Curr.Microbiol.App.Sci. 10(01): 3159-3164.

doi: https://doi.org/10.20546/ijcmas.2021.1001.368 